\title{
Louisa Alice Baker, 1856-1926
}

\section{Kirstine Moffat}

Louisa Baker was the first New Zealand woman to succeed in making a career out of writing novels, publishing seventeen books between 1894 and 1910. Significantly, this success was only possible when Baker left New Zealand to pursue her literary career in England, a departure that later authors, such as Jane Mander and Katherine Mansfield, were to follow. The contemporary appeal of Baker's fiction lies in its blend of topical issues with romantic melodrama and exotic New Zealand settings. The novels, at their best, are intellectually challenging. Baker is primarily a theological writer who critiques the retributive austerity of Calvinism and advocates liberation through the transforming power of a Gospel of Love. These ideas underpin Baker's moral feminism. In her writing, love is the central ingredient to human happiness. Marriages without love are doomed and should end. With love relationships flourish and transgressions arising out of love, even sexual lapses, should be forgiven. This originality of thought is at times matched by stylistic innovations. Baker experiments with multi-perspective narratives, interior monologues and dream sequences and uses music and landscape (particularly bush, mountains and rivers) in a symbolic way. However, her prose can be overtly didactic and her writing relies on sentimental Victorian clichés. Death-bed reunions, discoveries of long-lost heirs, murders, miraculous escapes and revelations of long-hidden secrets abound. Playing to her overseas audience, Baker locates her narrative action in the stark beauty of the South Island mountains and the isolated grandeur of the North Island bush. In her novels New Zealand represents raw emotion, primitive, instinctual artistic talent and freedom from claustrophobic ideologies. However, her middle class, European heroes and heroines frequently depart for the cultural environs of Australia and England or arrive in New Zealand from overseas cities on missions of intellectual liberation.

Born on 13 January 1856 in the Warwickshire town of Aston in England, Louisa Alice was the second of five children born to Elizabeth (nee Bratt) and Henry Joseph Dawson. A carpenter by trade, Henry Dawson was also a parttime town missionary and preacher. Hints in Baker's fiction suggest that this religious background, which shaped her early thinking, was strongly Protestant, probably either Methodist or Brethren in denomination.

When Louisa was seven the Dawson family came to New Zealand through the assisted immigration scheme, arriving in Lyttleton on the Lancaster Witch in October 1863. They settled in Christchurch, where Louisa was educated. 
From a young age Louisa's literary ambitions were evident, seen in her submission of stories and articles to newspapers.

On 7 November 1874, at the age of eighteen, Louisa married John William Baker. He was thirty-three years old, a house painter by profession and an amateur Greek scholar. Two children were born of the union, a son, John William Walter (known as Jack), in 1875 and a daughter, Ethel Elizabeth, in 1877. During the 1870s Baker continued to pursue her literary goals, publishing stories such as 'Fickle Jack' and 'Grandmother's Story' in the Otago Witness.

Baker's marriage was an unhappy one and in July 1886 she left her husband and moved to Dunedin with her daughter. Louisa and John were never reconciled, although they did not divorce, and the family lived apart from this point, Baker making regular trips to Christchurch to see her son. John Baker died in Ashburton in 1916.

The move to Dunedin was motivated not only by Baker's need to remove herself from an unhappy marriage but also by her desire to further her career as a writer and journalist. In Dunedin she began work for the Otago Witness, an association that continued until her death. William Fenwick, the editor, employed Baker to help edit the children's page and write a column for women.

Baker was responsible for transforming the children's page. Up until her arrival in Dunedin the page had primarily been a collection of activities to amuse children. Baker believed that the page should also have an educational value. She invented the persona 'Dot' and 'Dot's Little Folk Page' was born. As 'Dot' she invited children to write to her. Her own children were the first correspondents, Jack praising a recent boat trip (16 July 1886) and Ethel describing her joy in receiving a present (23 July 1886). Soon 'Dot' was receiving letters from children throughout Otago. Some asked for advice about issues such as the care of pets and correct behaviour, while others contributed poems and stories. As 'Dot' Baker answered these and contributed her own children's stories to the page. Such was the success of Baker's innovation that 'Dot's Little Folk Page' became an institution in the Otago Witness and then in the Otago Daily Times, the title 'Dot' long outliving her creator.

A similar revolution was initiated by Baker in relation to the ladies' page. Prior to Baker's tenure with the paper this largely consisted of society gossip and hints for home management. Baker wrote a personal letter to readers, using the pseudonym 'Alice', and included her own original works of fiction. These letters reflect Baker's moral, feminist outlook and perhaps provide hints of the reasons behind the breakup of her marriage. Her letter of 23 July 1886 speaks of the gentle and uplifting influence a woman can have on her 
husband as long as he is not 'a brute or animal who merely regards a wife as a domestic drudge'.

Over the next few years 'Alice's' letters demonstrate an increasingly militant feminism. In a September 1893 issue of the Otago Witness Baker asks 'Why do men ask that women should sit in the shadow of their throne?' and calls on women to escape from the 'chains' that bind them and to embrace change. At this time Baker was active in the women's movement in both Dunedin and Christchurch. She was present at the September 1893 meeting of the Canterbury Women's Institute Economic Committee when Kate Sheppard received a telegram informing her that women had finally won the franchise. The women at this meeting praised Baker's work for the Otago Witness, declaring that other papers needed to treat women as intellectual beings rather than as devotees of fashion and gossip.

Baker's serial 'Chalk', which ran over several issues of the Otago Witness in 1886, is typical of her fiction at this time. The story, revolving around the fortunes of a poor Birmingham girl, combines affecting pathos with a serious engagement with social issues, particularly the abuse and neglect of children.

During the early 1890s Baker began to pursue more serious literary ambitions, writing her first novel (later published as A Daughter of the King). However, she struggled to find a publisher in New Zealand and set sail for England in 1894. Her daughter Ethel accompanied her, but her son Jack remained in Christchurch where he later married. Baker never saw him again, but wrote regularly and sent him copies of all her novels.

Baker's predicament was typical of the dilemma facing creative artists in colonial New Zealand. The New Zealand reading public had an appetite for things British and the few publishing companies based in New Zealand were reluctant to publish works by unknown local authors. Baker had no option but to pursue her literary dream overseas. She commented that she was 'bred under the Southern Cross, held cheaply there - and labelled in London' (McCallum, p. 27). This 'labelling' refers to her adoption of yet another pseudonym, that of 'Alien'. This speaks of both her sense of dislocation from her New Zealand home and her sense of isolation as a professional and artistic woman in a patriarchal environment.

Successfully securing a publisher when she reached London, Baker's first novel, A Daughter of the King, was published in 1894. This is the most stylistically innovative and intellectually challenging of Baker's novels, establishing tropes that she returned to again and again in subsequent novels.

A Daughter of the King is a bildungsroman tracing the spiritual and moral evolution of the heroine. Florence's dying father leaves her with the legacy of a loving God, but this is obscured by the harsh puritanical faith of her adoptive 
mother. An unhappy sacrificial marriage triggers rebellion and Florence departs for Melbourne to seek meaning in a succession of philosophies. Truth, feminism, humanism and work are all trialed and found wanting, but eventually Florence hears a preacher talk of the Gospel of Love and recaptures her father's faith: 'I am a daughter of the King! Eternal Life, Eternal Truth, Eternal Love, are mine by right in God' (294). Baker's feminist beliefs also emerge clearly. Although the redeemed Florence returns to bring succour to her dying husband, Baker advocates separation and divorce as a necessary end to an unloving relationship, which she regards as 'respectable sin' (153). Florence is typical of Baker's heroines. Instinctively cultured and fiercely independent she eventually needs to leave the Canterbury environs that have nurtured her as a child for the artistic opportunities of Melbourne, where she becomes an acclaimed violinist. Yet, running counter to her feminist individualism, there is a strong self-sacrificial strain in Florence which is nurtured by her conversion to a Gospel of Love that idealises renunciation.

Baker's writing style is, at times, not quite up to the intellectual demands of her feminist and theological ideas. However, she does make use of interior monologues, multi-perspective narrative voices and mystical dream sequences, which are innovative for her time. While the New Zealand of her novel remains an exotic backdrop representative of a primitive, instinctual Nature (as opposed to Australia which represents Art and Culture), Baker is capable of using landscape in a powerfully symbolic way. In A Daughter of the King the opening scene by the Avon River in Christchurch establishes a metaphor for the vicissitudes of life. Likewise, this text establishes Baker's trademark connection between music and ideal femininity. Florence's ability to play the violin is fostered by the beauties of the New Zealand natural environment and is indicative of her independence, rich emotional life and rejection of Calvinist austerity and self-denial.

A Daughter of the King was greeted with warmth by English reviewers, who described it as a 'clever novel' which showed 'remarkable promise' (New Zealand Mail, 26 April 1895). One critic tempered his praise with a request that Baker 'avoid "yellow-asterics" and "problems" ' in the future and another was confused as to the author's gender and place of residence, referring to 'Mr Baker of Christchurch', but the novel was accepted by an American publisher and sold so well in England that it went to a second edition (New Zealand Mail, 30 November 1894, 26 April 1895). This publishing pattern set the trend for Baker's subsequent novels, all of which draw on the ideas and motifs of $A$ Daughter of the King. For the next fifteen years she produced a novel a year.

Baker's second novel, The Majesty of Man (1895) provides the back-story of the preacher who brought theological enlightenment to Florence in $A$ 
Daughter of the King and introduces a second type of Baker protagonist, the reclusive and spiritually tortured male. St John's Melbourne mission is an act of atonement for his accidental killing of a friend. Eventually he is reunited with his wife and returns to the New Zealand of his childhood. The theme of self-sacrifice, this time to expiate the sins of another, is also central to In Golden Shackles (1896). A novel of the goldfields, Baker uses the realistic setting to critique materialism and greed. Baker's moral feminism also emerges clearly in The Majesty of Man. The celibacy of Sister Lilian in applauded, but is seen as ultimately cold and sterile when contrasted with domestic love. A similar celebration of passion over intellect underpins the Canterbury bildungsroman Wheat in the Ear (1898). Baker's insistence that women are sexual as well as intellectual and moral beings is unusual for its time, the New Zealand feminist writers Ellen Ellis and Edith Searle Grossmann viewing sex as a male invasion of female independence. The river imagery in the text reinforces the central message of female passion, as well as conveniently freeing the heroine to fulfill that passion through the death of the husband she does not love in a convenient flood.

The issue of marriage and male-female relations is central to Baker's next two New Zealand novels. The Untold Half (1899), set in the spectacular landscape of the Lake Manapouri forest, is the most risqué of Baker's novels, the only one to deal with a sexual relationship outside of marriage. Baker's feminist and theological beliefs intertwine in this novel, the heroine absolved of her moral transgression because she acted out of love: 'some sins seem purer than other virtues and lift higher' (356). In contrast, Another Woman's Territory (1901) asserts the sanctity of marriage. Caroline Grey forbids Geraldine Ward, rival for her husband's affections, to come near Howard: 'You are on another woman's territory...I am his wife.' (287-8). The sub-plot of this novel is a fascinating analysis of the consequences of stealing the plot of a best-selling novel from an unpublished manuscript.

The Devil's Half Acre (1900) and Not In Fellowship (1902) return to the theological issues of Baker's first novels. Both of these are damning critiques of Calvinist theology. The Devil's Half Acre is an exposé of fire and brimstone preaching. John Jermyn lambasts the residents of a South Island mining community with his message of a God of wrath and judgement as he seeks to propitiate that God for his adultery with and murder of his childhood sweetheart. Not in Fellowship attacks the exclusivity of Calvinist congregations, which stand in need of the liberating influence of the natural environment and new ideas. This is provided by another of Baker's favourite character types, a cultured Englishwoman with an enlightened outlook and a musical talent, this time for song, indicative of her ethic of inclusion and 
forgiveness. In both texts Baker's Gospel of Love ultimately brings liberation and redemption.

Not in Fellowship was Baker's last New Zealand novel for five years. In 1902, feeling that her memories of New Zealand were fading, she turned to English settings for inspiration. The novels which followed are much less complex and intellectual than their New Zealand counterparts and do not make use of symbolic landscapes. A conventional blend of romance and melodrama, these plot-driven narratives are clearly written for financial rather than ideological reasons. Some of the standard Baker moral themes are present - renunciation of a great love in Over the Barriers (1903), the virtues of female independence and the evils of class division in A Slum Heroine (1904), the compensations of artistic creation in An Unread Letter (1909), redemption through suffering in $A$ Double Blindness (1910) and relinquishment of revenge in An Unanswered Question (1906) - but they are much less substantial than in the New Zealand texts, always secondary to the demands of the romantic narrative.

In 1903 Baker re-established her connection with the Otago Witness, contributing a weekly column, 'Alice's Letter From England', to the Iadies' page. While, as in her novels, English news (particularly cultural events, fashion and royal gossip) formed a substantial part of her letters, Baker continued to promote women's suffrage and offered comments on contemporary issues such as war, divorce and politics. She also continued to write for English periodicals and worked as a reader for a London publishing house.

Baker reverted to a New Zealand setting in two later novels. This reengagement with New Zealand was coupled with a return to complex moral issues. In His Neighbour's Landmark (1907) all the standard Baker ploys reemerge: the reclusive male in need of redemption, the instinctively cultured, musical, independent woman, the relinquishment of self-interest out of love, the freedom offered by 'the boundless space and the blue vaults of the Southern Cross', the nurturing possibilities of the bush, and the need for artistic talent (in this instance an operatic voice) to be developed in England (2). The novel also contains a dramatic set piece in which the Tarawera eruption temporarily parts the lovers. Baker's moral feminism is particularly evident in The Perfect Union (1908), another anti-Calvinist text in which the mountains of the Otira Gorge symbolise the liberating possibilities of a God of love. The heroine, Alma (another of Baker's cultured and enlightened Englishwomen with a talent for song and piano playing), contemplates a freelove union but eventually realises that this would be 'a sin against her womanhood' and that only in marriage can a 'perfect union' be found (183). 
In spite of its strong moral message, The Perfect Union was attacked by New Zealand critics as belonging to a class of 'decadent books' in which 'evil' is 'wrapped up in high-flown language' (Smith, 71). This antagonism is typical of the New Zealand reaction to Baker's writing. She was chided for painting 'portraits of women who trifle with the sacredness of marriage' instead of presenting 'unblurred portraits of the ideal woman' (McCallum, 27). In her essay 'Colonials in Fiction' fellow novelist Clara Cheeseman attacked Baker for being 'somewhat too fond of what may be termed regrettable incidents' and complained that Baker's 'chief characters are almost always inconsistent' (279). However, by 1925 Baker's English and American popularity began to filter through to New Zealand. Fourteen of Baker's novels were on display at the 1925-6 South Seas International Exhibition in Dunedin. Baker was even hailed as 'a colonial George Eliot' in recognition of the moral purpose of her writing (Otago Witness, 30 May 1926).

In later life Baker lived alone at Britannia Cottage in Deal, Kent, but maintained regular contact with her daughter Ethel, who had married Englishman George Felix Edgar. She earned a living from the proceeds of her books and through freelance writing. Baker was active and in good health until she suffered severe burns while extinguishing a fire from a portable oil stove just after midnight on 21 March 1926. She was writing her column for the Witness at the time. After a neighbour saw her distress signal the next morning she was taken to the War Memorial Hospital where she died on 22 March. Her obituary in the Otago Witness described her as a woman with 'an engaging personality' who was 'a conscientious and faithful worker' (30 May 1926). The paper published her last story 'The Wrong Card', a romantic tale about lovers reunited during a World War I air raid, as a tribute to her literary talent.

Without the theological context and feminist agenda of her novels Louisa Baker would be little more than an exponent of Victorian melodrama. Her romantic narratives, melodramatic endings and use of sentimental clichés are exposed in her English novels. However, in her New Zealand novels the ideas and stylistic innovations redeem the sometimes overwrought prose. Her advocacy of divorce or separation to end an unhappy marriage, tolerance for sexual lapses, plea for equality within marriage, and insistence on female sexuality were radical for their day. Likewise, her critique of Calvinist doctrine and behaviour was at the forefront of a long New Zealand tradition of antiPuritan writing. Baker's enduring appeal is largely through the historical significance of her theology and moral feminism. Her largeness of vision was not entirely matched by her literary skill, but, like so many of her heroines, she made a name for herself in England and America, a rare achievement for a colonial New Zealand woman writer. 
LINKS

$\underline{D N Z B}$

NZETC

\section{Bibliography}

\section{BOOKS}

Note: all of Louisa Baker's fiction was published under the pseudonym 'Alien'.

A Daughter of the King. London: Hutchinson, 1894, Chicago: Neely, 1894.

The Majesty of Man. London: Hutchinson, 1895.

In Golden Shackles. London: Hutchinson, 1896; New York: Dodd, Mead, 1896.

Wheat in the Ear. London: Hutchinson, 1898, New York: Putnam's, 1898.

Looking Glass Hours, with 'Rita', pseudonym of Eliza Margaret J. Humphries.

London: Hutchinson, 1899.

The Untold Half. London: Hutchinson, 1899, New York: Putnam's, 1899.

The Devil's Half-Acre. London: Fisher Unwin, 1900.

Another Woman's Territory. Westminster: Constable, 1901, New York: Crowell, 1901.

Not in Fellowship. London: Digby Long, 1902.

A Maid of Mettle. Philadelphia: Jacobs, 1902; London: Digby Long, 1913.

Over the Barriers. London: Isbister, 1903.

A Slum Heroine. London: Digby Long, 1904.

An Unanswered Question and Other Stories. London: Digby Long, 1906.

His Neighbour's Landmark. London: Digby Long, 1907.

The Perfect Union. London: Digby Long, 1908.

An Unread Letter. London: Digby Long, 1909.

A Double Blindness. London: Digby Long, 1910.

\section{REFERENCES}

Cheeseman, Clara. 'Colonials in Fiction.' New Zealand Illustrated Magazine, 7 (January, 1903).

McCallum, Janet. 'Baker. Louisa Alice.' The Dictionary of New Zealand Biography Volume 3 - 1901-1920. Auckland: Auckland University Press, Department of Internal Affairs, 1996, pp. 27-8.

McLeod, Aorewa. 'Aliens: Two New Zealand Novelists of the First Woman's Movement.' Women's Studies Conference Papers, August 1989. Ed. Clare Simpson. Christchurch 1990: 35-43.

Moffat, Kirstine. 'The Puritan Paradox: an annotated bibliography of Puritan and antiPuritan New Zealand fiction, 1860-1940, part 1: the Puritan influence.' Kotare: New Zealand Notes and Queries, 3:1 (2000): 36-86.

Moffat, Kirstine. 'The Puritan Paradox: The Puritan Legacy in the Intellectual, Cultural and Social Life of New Zealand. Focusing Primarily on the Works of Novelists Writing Between 1862-1940.' PhD thesis, Victoria University of Wellington, 1999.

Moylan, Philippa. 'Paradigm and Promise: A Feminist Critique of Novels by E.S. Grossmann and L.A. Baker.' MA thesis, University of Auckland, 1990. 
Obituary. Otago Witness, 30 May 1926.

Old Writer's Association. Fifty Years: History of the Dot's Little Folk Page 1886-1936.

Dunedin: Otago Daily Times and Witness Newspapers, 1938.

'The Passing of Alien: A Sad Tragedy.' Otago Witness, 18 May 1926.

Roberts, Heather. Where Did She Come From? New Zealand Women Novelists 1862-1987. Wellington: Allen and Unwin, 1989.

Smith, Elizabeth Maisie. A History of New Zealand Fiction from 1862 to the Present Time With Some Account of Its Relation to the National Life and Character. Wellington: Reed, 1939.

Sturm, Terry, ed. The Oxford History of New Zealand Literature in English. $2^{\text {nd }}$ ed. Auckland: Oxford University Press, 1998.

Wattie, Nelson. 'Baker, Louisa Alice.' The Oxford Companion to New Zealand Literature. Eds. Roger Robinson and Nelson Wattie. Auckland: Oxford University Press, 1989, pp. 38-9. 